\title{
Üniversite Öğrencilerinin Covid-19 Virüsü Hakkında Bilişsel Yapılarının Belirlenmesi
}

\author{
İsmail DÖNMEZ ${ }^{1}$ ve Seraceddin GÜRBÜZ ${ }^{2}$ \\ $\ddot{\mathrm{O} z}$
}

Bu araştırmanın amacı covid-19 virüsü hakkında lisans ve önlisans öğrencilerinin bilişsel yapılarını belirlemektir. Nitel araştırma yöntemlerinden durum çalışmasının kullanıldığı bu araştırmada veri kaynaklarını demografik bilgiler, bilgi kaynağı ve kelime ilişkilendirme testi oluşturmuştur. 32 ilden 112 üniversite öğrencisinin katıldığı araştırmada veriler Google form aracılığ1 ile toplanmış, elde edilen veriler içerik analizi ile incelenmiştir. Araştırma sonucunda katılımcıların bilgi kaynağı olarak en çok televizyon ve sosyal medyayı kullandığı, güven kaynağ1 olarak Sağlık ve İçişleri Bakanlığının açıklamalarını göstermektedir. Katılımcıların Covid-19 hakkındaki bilişsel yapıları, Covid-19 sonuçları, bulaşma yolları, Covid'e yönelik algılar, özellikleri, bulașma nedeni, tedavisi, taşıyıcıları, korunma yolları, hastalık sürecinin özellikleri, basına yansımaları, Covid-19 görüldügü ülkeler olmak üzere 11 kategoriye ayrılmıştır. Bu kategoriler katılımcıların Covid-19 kavramı hakkında bilişsel yapılarının alg1, bulaşma nedeni ve korunma yolları üzerinde yoğunlaştı̆̆ı görülmüştür. Bunun yanında katılımcıların Covid-19 virüsü hakkında bazı kavram yanılgılarına da sahip olduğu görülmüsstür.

Anabtar Kelimeler: Bilişsel yap1, Covid, Covid-19, Korona, Koronavirüs

\section{Determining the Cognitive Structures of University Students on Covid-19 Virus}

\begin{abstract}
The purpose of this research is to determine the cognitive structures of undergraduate and associate degree students about the covid-19 virus. In this study, in which case study, one of the qualitative research methods, was used, the data sources were composed of demographic information, information source and word association tests. In this study 112 participants undergraduate and associate degree students from 32 provinces participated, the data was collected via Google form, and the obtained data were analyzed by content analysis. As a result of the research, it shows that the participants mostly use television and social media as a source of information and the statements of the Ministry of Health and Interior Affairs as a source of trust. Cognitive structures on the concept of "Covid-19" were gathered under 11 categories using the independent word association test of university students. These categories are Covid-19 results, ways of transmission, perceptions about Covid-19, its features, cause of infection, treatment, carriers, ways of protection, features of the disease process, reflections to the press and countries in which Covid-19 is seen. It was observed that the cognitive structures of the participants about the concept of Covid-19 focused on the perception, cause of transmission and the ways of protection. In addition, it was observed that the participants had some misconceptions about the Covid-19 virus.
\end{abstract}

Key Words: Cognitive structure, Covid, Covid-19, Corona, Coronavirus

\section{Atıf İçin / Please Cite As:}

Dönmez, İ. ve Gürbüz, S. (2020). Üniversite öğrencilerinin Covid-19 virüsü hakkında bilişsel yapılarının belirlenmesi. Manas Sosyal Araștırmalar Dergisi, 9(4), 2159-2172. 


\section{Giriş}

Koronavirüsler $(\mathrm{CoV})$, soğuk algınlı̆g gibi toplumda yaygın görülen, kendi kendini sınırlayan hafif enfeksiyon tablolarından, "Orta Doğu Solunum Sendromu (MERS)" ve "Ağır Akut Solunum Sendromu (SARS)" gibi daha ciddi enfeksiyon tablolarına neden olabilen büyük bir virüs ailesidir (Dünya Sağlık Örgütü [WHO], 2019). Koronavirüslerin insanlarda bulunan, insandan insan kolaylikla bulaşabilen çeșitli alt tipleri (HCoV-229E, HCoV-OC43, HCoV-NL63 ve HKU1-CoV) bulunmaktadır. İnsanlar arasinda dolaşan bu alt türler çoğunlukla soğuk algınlı̆̆ına sebep olan virüslerdir. Bununla birlikte hayvanlarda saptanan birçok koronavirüs alt türü mevcuttur ve bu virüslerin hayvanlardan insanlara geçerek insanlarda ağır hastalık tablolarına neden olabildiği bilinmektedir. Detaylı araştırmalar sonucunda, SARSCoV'un misk kedilerinden, MERS-CoV'un ise tek hörgüçlü develerden insanlara bulaştığı ortaya çıkmışır (Halk Sağllğı Güvenlik Merkezi [HSGM], 2020). SARS-CoV, 21. yüzyllın ilk uluslararası sağlık acil durumu olarak 2003 ylında, daha önceden bilinmeyen bir virüs halinde ortaya çıkmıs olup yüzlerce insanın hayatını kaybetmesine neden olmuştur. Yaklaşık 10 yll sonra koronavirüs ailesinden, daha önce insan ya da hayvanlarda varlığı gösterilmemiş olan MERS-CoV, Eylül 2012'de ilk defa insanlarda Suudi Arabistan'da tanımlanmış; ancak daha sonra aslında ilk vakaların Nisan 2012'de Ürdün Zarqa'daki bir hastanede görüldüğü ortaya çıkmıştır (WHO, 2019).

29.12.2019 tarihinde görülen baz1 zatürre (pnömoni) olgular1 Huanan Deniz Ürünleri Pazar1 ile ilişkilendirilmiş, 31.12.2019 tarihinde de Wuhan Sağllk Komisyonu, Çin Halk Cumhuriyeti Ulusal Sağlık Komisyonu ve Çin Halk Cumhuriyeti Hastalık Kontrol ve Korunma Merkezi tarafindan yeni bir salgının varllğı dünyaya duyurulmuştur. 08.01.2020 tarihinde bu yeni salgının sorumlusu olarak yeni bir korona virüsün varlığı Çin Halk Cumhuriyeti Hastalık Kontrol ve Korunma Merkezi tarafindan resmi olarak ilan edilmiştir. 31 Aralık 2019'da Dünya Sağlık Örgütü, Çin Ülke Ofisi, Çin'in Hubei eyaletinin Wuhan şehrinde etiyolojisi bilinmeyen pnömoni vakalarını bildirmiştir. 7 Ocak 2020'de etken daha önce insanlarda tespit edilmemiş yeni bir koronavirüs (2019- nCoV) olarak tanımlanmıştır. Daha sonra 2019-nCoV hastalı̆̆ının adı Covid-19 olarak kabul edilmiş, virüs SARS CoV'e yakın benzerliğinden dolayı SARS-CoV2 olarak isimlendirilmiştir (Li vd., 2020, s. 1200). Covid-19 virüsü tüm Dünya'da hızlı bir şekilde yayılmış 07.05.2020 tarihi ile 3.954.897 kişiye bulaşmış 275.179 kişinin ölümüne neden olmuştur (John Hopkins Corona Virus Research Center, 2020). Türkiye'de ise bu sayı aynı tarihte 127.659 vaka ve 3461 vefat sayısına ulaşmıştır. Dünya Sağlık örgütü virüsün yayılmasını pandemi olarak ilan etmiştir. Dünya genelinde meydana gelen pandemilerin hemen ardından sosyolojik ve politik değişimler yaşandığı görülmüştür (Kırık ve Özkoçak, 2020, s. 135). Ülkeler ve yerel yönetimler, koronavirüs (Covid-19) pandemisinin yayılmasını yavaşlatmak amacıyla, ev hapsi, seyahat yasakları ve okul kapatma gibi tedbirler almak zorunda kalmışlar, okulların kapatılmasıyla birlikte milyonlarca çocuk, genç, ve yetişkin, okullara ve üniversitelere gidememesine neden olmuştur (Can, 2020, s. 13). Virüsün özellikle yaşlı gruplarda ve kronik hastalarda yüksek ölüm oranlarına ulaşması insanların artan sosyal ve aile desteği almalarına sebep olmuş, insanlar dehşete kapılmış ve endişeli hissettiklerini bildirmişlerdir (Zhang ve Ma, 2020, s. 1). Özellikle sosyal izolasyonun artmasıyla birlikte toplum daha çok evde vakit geçirmeye başlamıştır. Bu durum sosyal medya kullanımını giderek arttırmaya başlamıştır (Kırık ve Özkoçak, 2020, s. 145). Bu nedenle, sosyal medya kullanımı veya internet kullanımı veya haber takibi ile ilgili sorular, bu tür salgınların ruh sağlığı üzerindeki etkisi olduğu görülmüştür (Zhang ve Ma, 2020, s. 12).

Koronavirüs nedeniyle gerek geleneksel medyada gerekse sosyal medyada büyük bir bilgi kirliliği meydana gelmiştir. WHO, Covid-19 salgınının yayılmasını yavaşlatma çabasına öncülük etmektedir. Ancak, sosyal medya platformları ve diğer kurumlar aracılı̆̆ıla hızla yayılan küresel bir yanlış bilgilendirme salgını, halk sağlığı için ciddi bir sorun oluşturduğu ifade edilmiştir (Kırık ve Özkoçak, 2020, s. 149). Kısacası bu dönemlerde sadece bir salgınla değil, yanlış ve taraflı haberler ve düşünceler ile de savaşılmaktadır (Zarocostas, 2020, s. 676). Dolayısıyla devlet kurumlarının kriz süreçlerini iyi yürütmeleri gerekmektedir. İç iletişim ve yönetim terimleriyle ifade etmek gerekirse: bir kurum bir krize yanıt vermediğinde veya yanıtı çok yavaş olduğunda, güvenilirliğini kaybeder ve diğer aktörlerin söz konusu krizi çerçevelendirmesine kap1 açar (Lugo, 2020, s. 1).

Krizler toplumların alışkanlıklarının değişmesi yanında yeni kavramların (virüs, pandemi, sosyal izolasyon, karantina) hayatımıza girmesine sebep olmuştur. Oldukça geniş kullanım alanının olması virüs kavramını öğrenilmesi ve öğretilmesi zor olan kavramlardan biri haline getirerek, bilişsel yapılarını oluşturmalarında zorlanmalarına neden olmaktadır. Bilişsel yapı, bir kişinin uzun süreli belleğindeki kavramların ilişkilerini simgeleyen ve varsayıma dayanan bir yapıdır. Çünkü kavramlar tek başına bir anlam ifade etmekte yetersiz kalabilmektedirler. Kavram kendisinin anlamını taşıdığ diğer kavram grubuyla 
ilişkilendirildiğinde söz konusu kavramla ilgili anlamı ve öğrencilerin bilişsel yapıları ortaya çıkmaktadır (Kurt ve Ekici, 2013, s. 811).

Bilişsel yapı, öğrenenin uzun süreli hafızasındaki kavramların organizasyonunu ve aralarındaki ilişkiyi gösteren varsayımsal bir yapıdır (Shavelson, 1974, s. 234). Öğrenenin bilişsel yapısının tanımlanmasında iki temel eleman vardır. Bunlardan birincisi; bilişsel yapının içerdiği bilgi birimleri, ikincisi ise bu birimlerin nasıl organize edildiğidir (West, Fensham ve Garrard, 1985, s. 30). Özellikle son yıllarda fen alanında yapılan araştırmalarda veri toplamak amaciyla kullanılan bu tekniğin (Torkar ve Bajd, 2006, s. 5; Timur ve Taşar, 2011, s. 131) öğrencilerin bilişsel yapıların belirlenmesi için kullanıldığ1 görülmektedir (Ekici, Gökmen ve Kurt, 2014, s. 362). Bağımsız kelime ilişkilendirme testi kavramlarla ilgili, bireylerin bilişsel yapısını ve bu yapıdaki kavramlar arası bağları, yani bilgi ağını özümlemek, uzun dönemli hafızasında bulunan kavramlar arasındaki ilişkilerin yeterli olup olmadığını tespit etmek amacıyla kullanılan en yaygın tekniklerden biridir (Ekici, Gökmen ve Kurt, 2014, s. 362). Fen eğitiminde özellikle biyoloji kavramlarına ilişkin enzim (Kurt, 2013, s. 211), virüs (Ekici ve Kurt, 2014, s. 267), genetik (Bahar, Johnstone ve Sutcliffe, 1999, s. 134), genetiği değiştirilmiş organizmalar (GDO) (Gerçek, 2020, s. 96) gibi bilişsel yapılara dair çeşitli araştırmalar görülmektedir. Tüm bu çalışmalarda kullanılan yöntem ve teknikler, bilim alanındaki bilişsel yapıların seviyesini belirlemeyi ve yükseltmeyi amaçlamaktadır. Bu konuda önemli tekniklerden biri sözcük birleştirme tekniği öğretimde olumlu sonuçlar vermektedir (Kostova ve Radoynovska, 2008, s. 211). Bireylerin nasıl düşündükleri, hatırladıkları, bilgileri nasıl organize ettikleri gibi konular yıllarca eğitim araştırmalarının en fazla merak edilen ve üzerinde araştırmalar yapılan en önemli konularının başında gelmektedir. Günümüzde büyük bir sorun haline gelen Covid-19 virüsünün neden olduğu pandemi durumu hem sosyal araştırmalar hem eğitim uygulamalarında etkisi olduğu görülmektedir. Ayrıca, Covid-19 virüsü ile ilgili araştırmalar devam etmesine karşın virüsün sağlık, politika ve eğitim alanlarındaki literatürde önemli boşluklar bulunmaktadır. Eğitime ilişkin bulgular ve sonuçlar dikkatle yorumlanmalıdır, çünkü Covid-19 pandemi süreci hakkında çok az yayınlanmış araştırma bulunmaktadır. Araştırma da elde edilecek bulguların ileride yapılacak çalışmalara katkı sunacağı düşünülmektedir.

$\mathrm{Bu}$ araştırmanın amacı üniversite (ön lisans ve lisans) öğrencilerinin "Covid-19" kavramı hakkında bilişsel yapılarını belirlemektedir. Bu amaç doğrultusunda şu alt problemlere yer verilmiştir.

1. Katılımcilar, Covid-19 hakkında nereden bilgi almaktadır?

2. Katılımcılar, Covid-19 hastalığından korunmak için alınacak önlemler hakkında hangi kaynaklara güvenmektedir?

3. Katılımcılar, Covid-19 Salgını acil durumunun yönetimi hakkında kurum, kuruluş, kişilerin çalışmalarını nasıl değerlendirmektedir?

4. Katılımcıların Covid-19 salgını hakkındaki bilişsel yapılanı nelerdir?

5. Katılımcıların bilişsel yapılarında Covid-19'a yönelik kavram yanılgıları var mıdır?

\section{Yöntem}

$\mathrm{Bu}$ araştırmada nitel araştırma yöntemlerinden durum çalışması kullanılmıştır. Durum çalışmasına karmaşık sosyal olguları anlama isteğidir (Stake, 1995, s. 12). Yin’e (2014, s. 45) göre durum çalışmas1, güncel olan ve araştırmacı kontrolünün değisskenler üzerinde olmadığı durumlarda nasıl ve neden sorularını cevaplamak için kullanılan bir araştırma yöntemidir. Yıldırım ve Şimşek'e (2011, s. 39) göre durum çalışması, nasıl ve niçin sorularını temel alarak araştırmacının kontrol edemediği bir olgu ya da olayı derinliğine incelemesine olanak veren araştırma yöntemidir.

\section{Katılımcilar}

Katılımcıların görüşlerini almak için online form kullanılmıştır. Online formu, 28.03.2020-28.04.2020 tarihleri arasında 36 ilden 112 katıllımcı doldurmuştur. Katılımcıların yüzde 58’i ( $\mathrm{f}=65$ ) ön lisans, yüzde 42'si (f=47) lisans öğrencisidir. Araştırmaya 18 - 33 yaş aralığında üniversite öğrencileri katılmıştır. 18 yaş grubun $\% 5,19$ yaş grubunda $\% 15,20$ yaş grubunda $\% 19,21$ yaş grubunda $\% 16,22$ yaş grubunda $\% 11$ olduğu görülmüştür. Katıllımcıların \%74'ü ( $\mathrm{f}=83)$ kadın, \%26'sı (f=29) erkektir. Bulgular bölümünde katılımcilar K1, K2, K3.....K112 şeklinde kodlanmıştır.

\section{Veri Toplama Araçları}

Araştırmada veri toplama aracı iki bölümden oluşmaktadır. Birinci bölümde katılımcının yaş, cinsiyet, yaşadığ şehir gibi demografik özelliklerinin yanında Covid-19 hakkında nereden bilgi alıyorsunuz? Covid19 hastalığından korunmak için alınacak önlemler hakkında hangi kaynaklara güveniyorsunuz? Covid-19 
salgını acil durumunun yönetimi hakkında, aşağıdaki kurum, kuruluş, kişilerin çalışmalarını nasıl değerlendiriyorsunuz? gibi sorular yöneltilmiştir. İkinci bölümde katılımcıların Covid-19 kavramına ilişkin bilişsel yapılarını belirlemek amacıyla kelime ilişkilendirme testi kullanılmıştır. Atasoy (2004, s. 42)'a göre kelime ilişkilendirme testi, kavramlarla ilgili bilişsel yapıyı ve bu yapıdaki kavramlar arası bağları çözümlemek, bireyin uzun dönemli hafizasında bulunan kavramlar arasındaki ilişkilerin niteliklerini tespit etmek gibi amaçlarla kullanılan en yaygın tekniklerden biridir. Kelime ilişkilendirme testi ile öğrencilerin zihinlerinde oluşturmuş oldukları kavramlar ortaya çıkarlabilir (Bahar, Johnstone ve Sutcliffe, 1999, s. 134). Bu teknik, zihne gelen fikirleri sınırlamadan bağımsız olarak uyarıcı kelimeyle ilişsili cevaplama varsayımına dayanır (Sato ve James, 1999, s. 167). Tüm veriler, Google form aracıllı̆g ile toplanmıştır. Katılımcıların kelime ilişkilendirme testi hakkında kısa bir bilgilendirme yapılmışır.

Uyarıc1 kelime: Covid-19

Kelime 1:

Kelime 2:

Kelime 3:

Kelime 4:

Kelime 5:

Cümle:

Katılımcı öncelikle kavram hakkında aklına gelen ilk beş kelimeyi yazmalıdır. Ardından yazdığ1 kelimelerle ilgili cümle kurmalıdır. Kurduğu cümle bilişsel yapısına ilişkin bir ilgi verirken, kavram yanılgılarına ilişkin bir değerlendirme sürecini de sağlamaktadır. Dolayısıyla çalışmanın tutarlı̆̆ı içinde önemlidir.

\section{Verilerin Analizi}

Birinci bölümde katılımcıların demografik özellikleri ve Covid-19 salgını hakkında görüşlerini belirlemek için frekans ve yüzde kullanılmıştır. İkinci bölümde kelime ilişkilendirme testi ile elde edilen verileri analiz etmek için içerik analizi kullanılmışır. İçerik analizi, araştırılan bilginin yaygınlaştırılması ve daha sonra yapılacak çalışmaların şekillenmesine katkı sağlayan araştırma sentezleridir (Suri ve Clarke, 2009, s. 416). İçeriğin analiz edilmesi ve yorumlanması sürecinde; (1) kodlama ve çıkarma aşaması, Google form ile elde edilen verilen Excel üzerine aktarılmış ve frekans tabloları şeklinde düzenlenmiştir. 536 frekans elde edilmiştir. Ancak bazı kavramların frekans değerinin 1 olması nedeniyle çıkarılmıştır. Dolayısıyla 439 kavram incelenmiştir. (2) kategori geliştirme aşaması, incelenen kavramlar Ekici ve Kurt (2014, s. 291) ifade ettiği kategoriler dikkate alarak düzenlenmiştir. (3) geçerlik ve güvenirlik aşaması, (4) raporlaştırma aşaması olmak üzere dört aşamada gerçekleştirilmiştir (Yıldırım ve Şimşek, 2011, s. 39).

\section{Geçerlik ve Güvenirlik}

Araştırmanın geçerliğini sağlamak için (1) Verilerin kodlanması ve veri analiz süreci kapsamında kavramsal kategoriye nasıl ulaşıldığıyla ilgili yapılanlar detaylı bir şekilde açıklanmıştır (Hruschka vd., 2004, s. 311), (2) Araştırmada elde edilen kategorilere her biri için onu en iyi temsil ettiği varsayılan katılımcının görüşlerinden örnekler seçilerek bulgular bölümünde sunulmuştur (Roberts ve Priest, 2006, s. 41) ve (3) Yorumlarda ilgili araştırmalar arası tutarlılık sağlanmaya çalıșılımıştır. Araştırmanın güvenirliğini sağlamak için iki bağımsız uzman tarafindan veriler incelenmiştir. Uzman görüşleri [Görüş birliği / (Görüş birliği + Görüş ayrillğı) x 100] formülü kullanılarak hesaplanmıştır (Miles ve Huberman, 1994, s. 55). Kodlayıcılar arasındaki ortalama güvenirlik \%95 olarak bulunmuştur. 


\section{Bulgular}

Bu bölümde araştırmanın alt amaçları doğrultusunda bulgulara yer verilmiştir.

\section{Katılımcılar “Covid-19 hakkında nereden bilgi almaktadır?” alt problemine ilişkin bulgular}

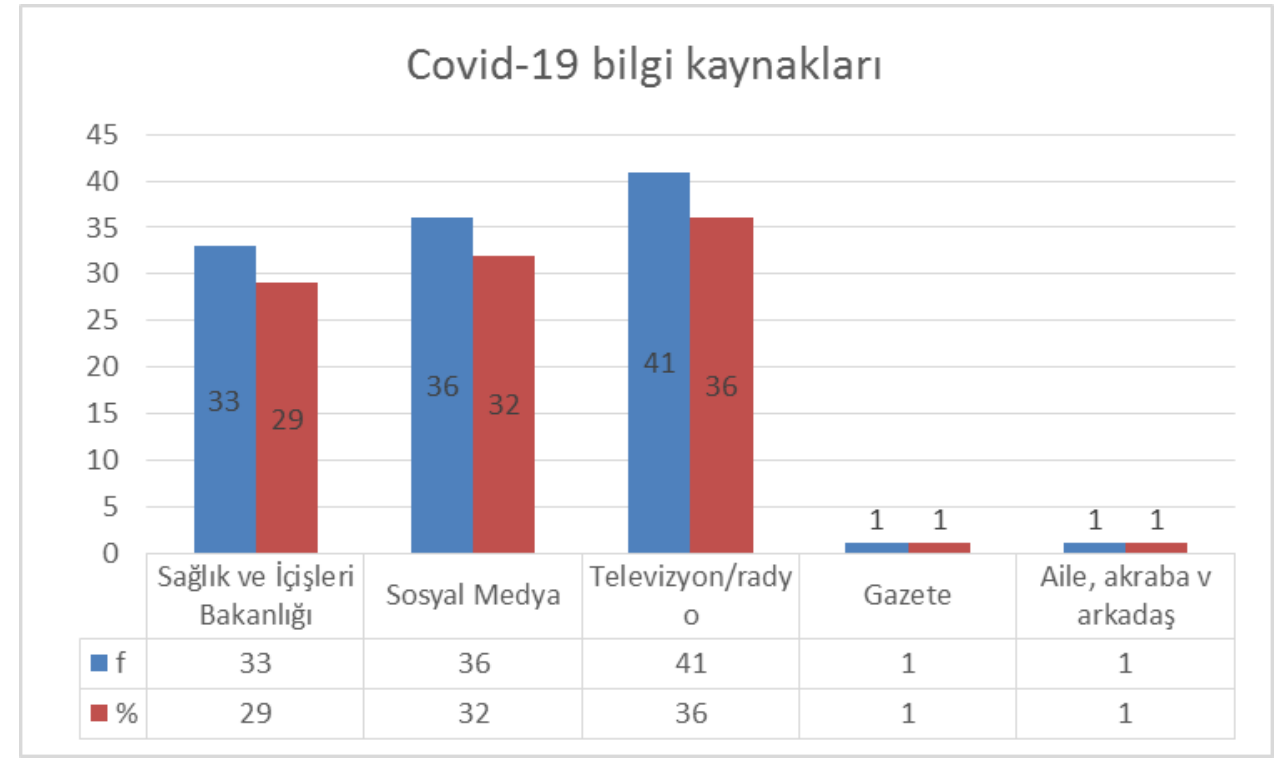

Şekil 1. Covid-19 Salgm Bilgi Kaynakları

Şekil 1.'de katılımcıların Covid-19 hakkında bilgi kaynakları görülmektedir. Katılımcıların Covid-19 salg1nı hakk1nda \%36's1 (f=41) televizyon ve radyodan bilgi edindiklerini, \%32'si (f=36)'s1 sosyal medyadan, \%29 (f=33)'u Sağlık ve İçişleri Bakanlı̆̆ından bilgi edindiklerini ifade etmektedir. Bu bulgular katılımcıların bilgi kaynaklarını televizyon ve radyodan aldıklarını göstermektedir. Ardından sosyal medyayı kullandıklarını ifade etmişlerdir.

"Katılımcıların Covid-19 hastalı̆̆ından korunmak için alınacak önlemler hakkında hangi kaynaklara güvenmektedir?” Alt problemine ilişkin bulgular

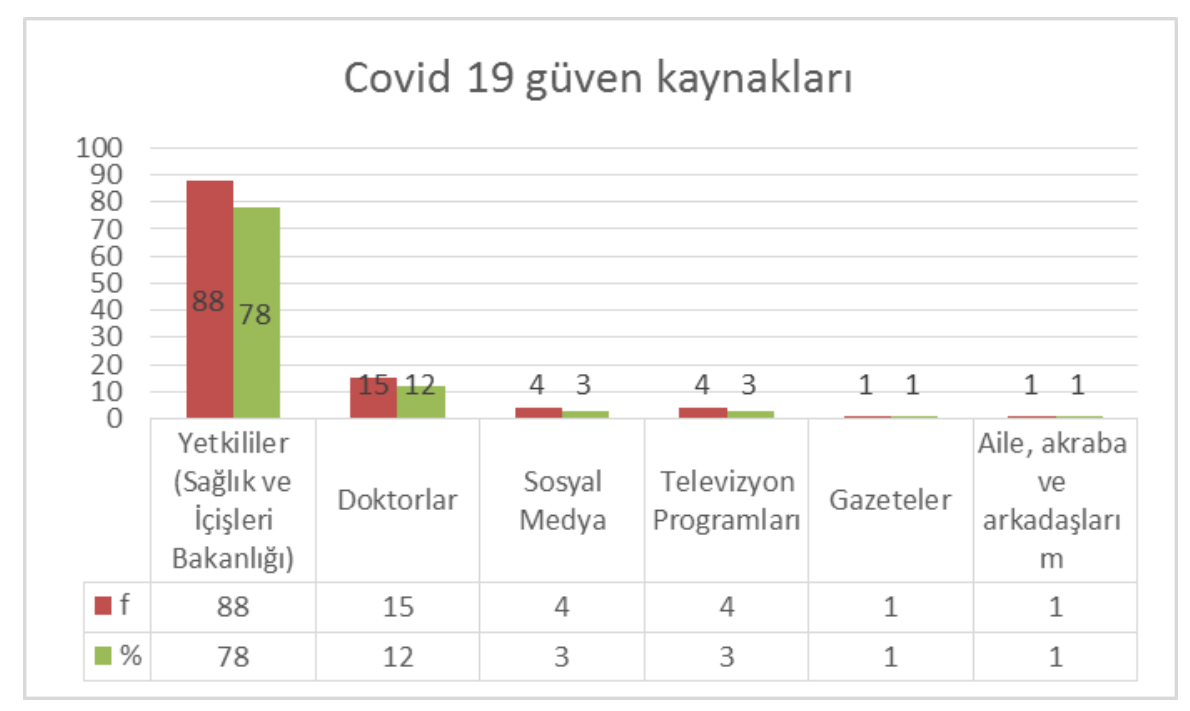

Şekil 2. Covid 19 Güven Kaynaklar

Şekil 2'de katılımcıların Covid-19 hakkında güven kaynakları görülmektedir. Katılımcıların \%78 ( $\mathrm{f}=88)^{\prime}$ 'i yetkililere, \%12 (f=15)'si doktorlara, \%3 ( $\left.\mathrm{f}=4\right)^{\prime} \mathrm{u}$ sosyal medyaya, \%3( $\mathrm{f}=4$ )' $\mathrm{u}$ televizyon programlarına güvendiklerini belirtmektedir. Bu bulgular katılımcıların güven kaynağının sağlık ve içişleri bakanlığ1 olduğunu göstermektedir. 
Katılımcılar, Covid-19 salgını acil durumunun yönetimi hakkında kurum, kuruluş, kişilerin çalışmalarını nasıl değerlendirmektedir? Alt problemine ilişkin bulgular

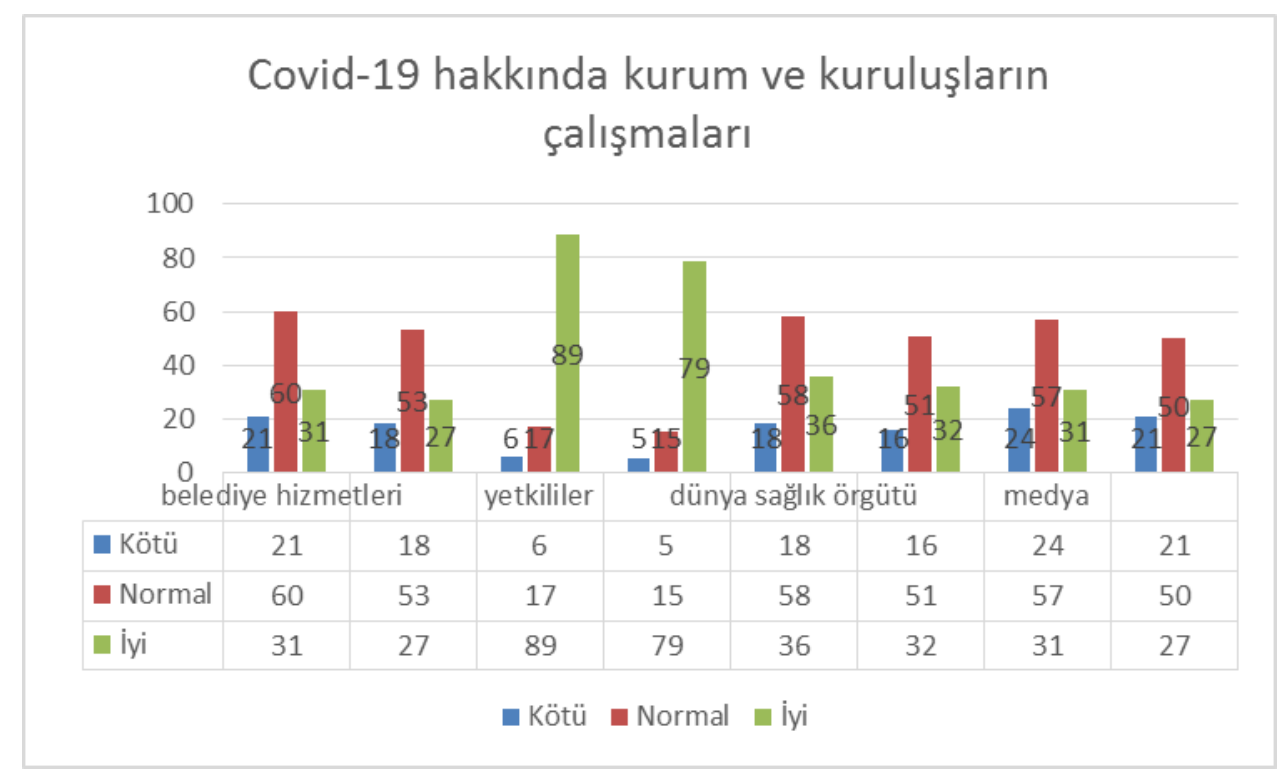

Şekil 3. Covid-19 Salgm Acil Durumunun Yönetimi Hakkeında Kurum, Kurulus, Kişilerin Calıs̆malar

Şekil 3’te katılımcıların Covid-19 Salgını acil durumunun yönetimi hakkında kurum, kuruluş, kişilerin çalışmaları hakkındaki görüşleri görülmektedir. Katılımcılar, kurum ve kuruluşlar içerisinde yetkilerin (Sağlık Bakanlı̆̆ı vb.) çalışmalarını \%79 ile olumlu olarak değerlendirmektedir. Ardından çalışmaların \%32 ile dünya sağlık örgütünün, \%27 ile belediye çalışmalarının, \%27 ile medya çalışmalarının göreceli olarak daha az başarısız olarak değerlendirildiği görülmektedir.

Katılımcıların Covid-19 salgını hakkındaki bilişsel yapıları nelerdir? Alt problemine ilişkin bulgular

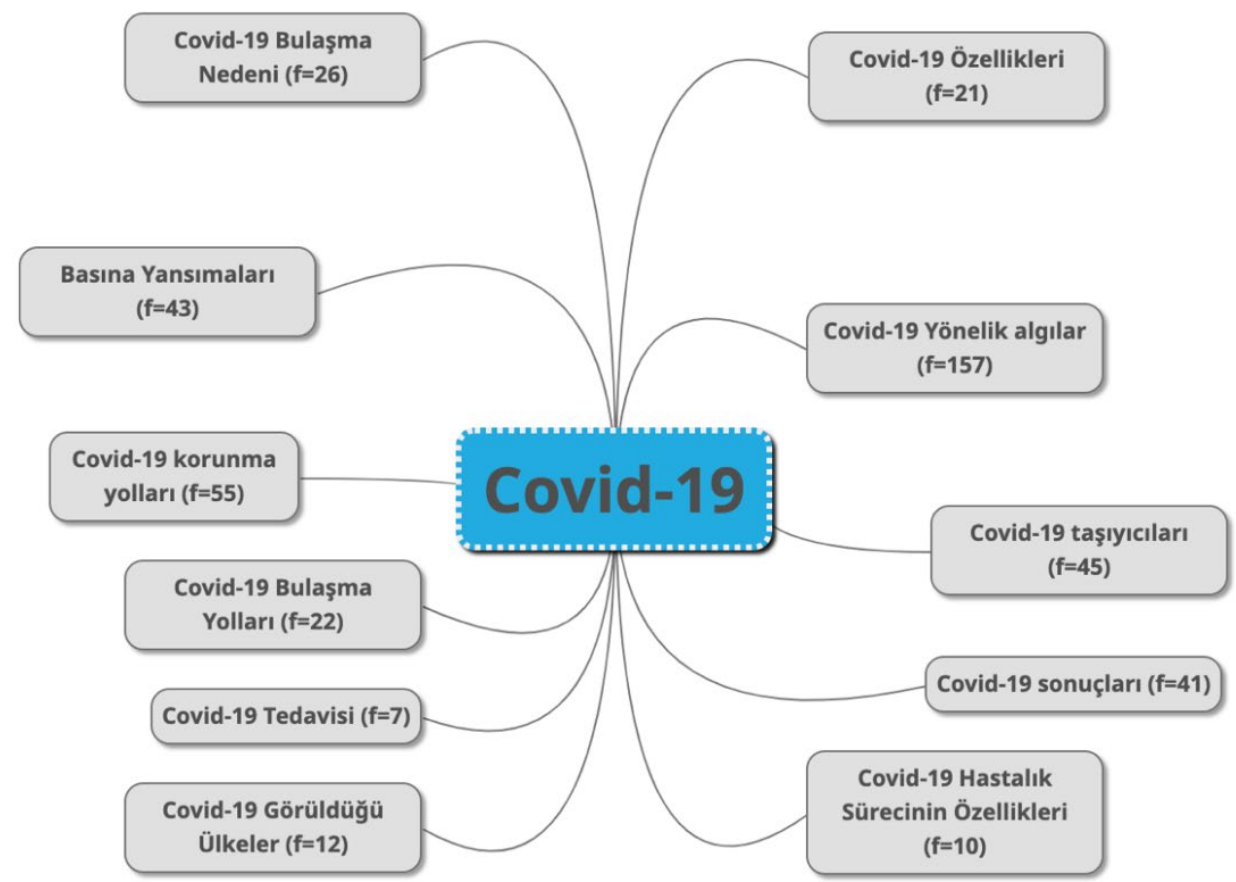

Şekil 4. Covid-19 Bilisssel Yapılar 
Şekil 4'de katılımcıların Covid-19 hakkındaki bilişsel yapıları 11 kategoriye ayıılmıştır. Covid-19 sonuçları, bulaşma yolları, Covid-19'a yönelik algılar, özellikleri, bulaşma nedeni, tedavisi, taşıyıcıları, korunma yolları, hastalık sürecinin özellikleri, basına yansımaları Covid-19 görüldüğü ülkeler olmak üzere 11 kategoriye ayrılmışır.

Tablo 1. Covid-19 Kavramı Hakeknda Kategori ve Kodlar

\begin{tabular}{|c|c|c|}
\hline Kategori & Kod & Toplam \\
\hline \multirow{3}{*}{ Covid-19 Sonuçları } & Hastalık-22 & 41 \\
\hline & Ölüm-15 & \\
\hline & Akciğer-4 & \\
\hline \multirow{2}{*}{ Covid-19 Bulaşma Yolları } & Temas-12 & 22 \\
\hline & Soluma-10 & \\
\hline \multirow{22}{*}{ Covid-19’aYönelik Alg1lar } & Sağlık-24 & 157 \\
\hline & Yaşam alanı-17 & \\
\hline & Doğa-10 & \\
\hline & Hayat-10 & \\
\hline & Yuva-10 & \\
\hline & Korku-10 & \\
\hline & Dünya-10 & \\
\hline & Kuş-8 & \\
\hline & Yaşam-8 & \\
\hline & Okul-8 & \\
\hline & Ac1-8 & \\
\hline & Ekonomi-4 & \\
\hline & Alışveriş-4 & \\
\hline & Çevre-4 & \\
\hline & Deniz-3 & \\
\hline & Endişe-3 & \\
\hline & Huzursuzluk-3 & \\
\hline & Psikolojinin bozulmas1-3 & \\
\hline & Toplum-3 & \\
\hline & Umutsuzluk-3 & \\
\hline & Eğitim-2 & \\
\hline & İletişim-2 & \\
\hline \multirow{3}{*}{ Covid-19 Özellikleri } & Ateş-10 & 21 \\
\hline & Öksürük-9 & \\
\hline & Yayilma-2 & \\
\hline \multirow{2}{*}{ Covid-19 Bulaşma Nedeni } & Virüs-20 & 26 \\
\hline & Korona-6 & \\
\hline \multirow{2}{*}{ Covid-19 Tedavisi } & Aș1-4 & 7 \\
\hline & Hastane-3 & \\
\hline \multirow{4}{*}{ Covid-19 Taşıyıcıları } & İnsan-18 & 45 \\
\hline & Hayvan-21 & \\
\hline & Aile-3 & \\
\hline & Hava-3 & \\
\hline \multirow{9}{*}{ Covid-19 Korunma Yollar1 } & Maske-10 & 55 \\
\hline & Önlem-10 & \\
\hline & Temizlik-10 & \\
\hline & Sosyal mesafe- 9 & \\
\hline & Dezantektan-4 & \\
\hline & El temizliği-3 & \\
\hline & Hijyen-3 & \\
\hline & Korunma-3 & \\
\hline & Tedbir-3 & \\
\hline Covid-19 Hastalık Sürecinin Özellikleri & Bulaşıc1-10 & 10 \\
\hline \multirow{5}{*}{ Basına Yansımaları } & Salg1n-22 & 43 \\
\hline & Karantina-9 & \\
\hline & Ev hapsi-4 & \\
\hline & Birlik-4 & \\
\hline & Pandemi-4 & \\
\hline \multirow{2}{*}{ Covid-19 Görüldüğü Ülkeler } & Çin-10 & 12 \\
\hline & Türkiye-2 & \\
\hline Toplam & & 439 \\
\hline
\end{tabular}


Tablo 1'de Covid-19 kavramına ilişskin kategoriler ve kodlar görülmektedir. Birinci kategoride Covid19 sonuçları hastalık, ölüm ve akciğer olarak sıralandığı görülmektedir. Bu kategoride 41 kavram sıralanmıştır. İkinci kategoride Covid-19 bulaşma yollarını temas ve soluma olmak üzere 22 kavram belirlenmiştir. Üçüncü kategoride Covid-19'a ait yönelik algılar incelenmiştir. Bu kavram sağlık, yaşam alanı, doğa, hayat, yuva, korku, dünya, kuş, yaşam, okul, ac1, ekonomi, alışveriş, çevre, deniz, endişe, huzursuzluk, psikolojinin bozulması, toplum, umutsuzluk, eğitim, iletişim olmak üzere 157 kavram sıralanmıştır. Dördüncü kategoride Covid-19 özellikleri sıralanmışır. Ateş, öksürük ve yayılma olmak üzere 21 kavram belirlenmiştir. Beşinci kategoride Covid-19 bulaşma nedenleri virüs ve korona olmak üzere 26 kavram belirlenmiştir. Altıncı kategoride Covid-19 taşııcıları sıralanmışır. Bu kategoride insan, aile, hayvan ve hava olmak üzere 45 kavram belirlenmiştir. Yedinci kategoride Covid-19 tedavisinde aşı ve hastane olmak üzere yedi kavram belirlenmiştir. Sekizinci kategoride Covid-19 korunma yolları, maske, önlem, temizlik, sosyal mesafe, dezenfektan, el temizliği, hijyen, korunma ve tedbir olmak üzere 55 kavram sıralandığı görülmektedir. Dokuzuncu kategoride Covid-19 hastalık sürecinin özellikleri bulaşıcı olması üzere 10 kavram belirlenmiştir. Onuncu kategoride basına yansımaları salgın, karantina, ev hapsi, birlik ve pandemi olmak üzere 43 kavram belirlenmiştir. On birinci kategoride Covid-19 görüldügü ülkeler Çin ve Türkiye olmak üzere 12 kavram belirlenmiştir. Bu bölümde kategorilerin oluşturma süreci ve nedenleri açıklanmıştır.

\section{Kategori 1. Covid-19 Sonuçları}

Bu kategori altında Covid-19'un sonuçlarını işaret eden kavramlara yönelik alıntıların analizi yapılmıştır.

K11: Virüs, sağhğgmıæn tehdit eden salgm hastalletrr.

K16: Corona virüsï denilen mikrobun bir an önce insanlara bulassp ölümcül sonuçlar doğurabilir, o yüzden berkesin maske kullamp ellerini her gün dezenfektan ile dezenfekte etmesi gereklidir.

K78: Covid-19 salgun hastalke sebebiyle ciğerlerde olusan tahribat ürkütücü bir hayat sundu evde yașamm güzelliğini de ögretti.

Katılımcılar "bastalke", "ölüm” ve "akciğger" kavramlarını ön plana çıkarmıştır. Covid-19'un başta kişilerin ve toplumun sağlığı olmak üzere olumsuz sonuçlarına vurgu yapıkları görülmektedir.

\section{Kategori 2. Covid-19 Bulaşma Yolları}

$\mathrm{Bu}$ kategori altında Covid-19'un bulaşma yollarını işaret eden kavramlara yönelik alıntıların analizi yapilmıştır.

K93: Virüsle mücadele de eldiven, maske takmak ve sosyal mesafeye dikeat etmek bizim virüsle temasimiz? engeller.

K61: Dünyada şu an gündemde olan Covid-19 çok teblikeli bir virüs olmakla beraber büyülk solunum sıkıntsst yasatur.

Katılımcılar "temas" ve "soluma" kavramlarını ön plana çıkarmıslardır. Katılımcıların Covid-19 virüsünün bulaşmasının yollarına vurgu yaptıkları görülmektedir.

\section{Kategori 3. Covid-19'a yönelik alg1lar}

Bu kategori altında Covid-19'a yönelik algılara işaret eden kavramlara yönelik alıntıların analizi yapılmışır. Bu kategori altında en fazla tekrarlanan kavramların yer aldığı görülmektedir.

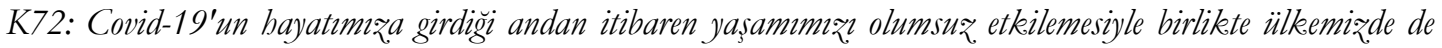
sağlık açısından büyü̈ tehdit uyandirmaktadir.

K96: Covid-19 yasam alammižn ev ortamina dönüstiü.

K95: Bilime önem verip gerekli önlemler almp doğaya önem verip Covid-19'dan kurtulmak mümkündür.

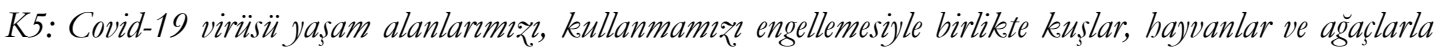
olan iliskimizi olumsuryönden etkilemis ve insanlar yuvalarna kapatmis durumda.

Katıllımcıların "sağhlk", "yaşam alanı" ve "doğa" gibi kavramları ön plana çıardıkları görülmektedir. Bu kavramlar Covid-19'a ait zihinsel algılarının sağlıklı kalma ve uzun süren karantina döneminde doğaya dönmek istemelerinin bir sonucu olabilir. 


\section{Kategori 4. Covid-19'un özellikleri}

Bu kategori altında Covid 19'a özelliklerine işaret eden kavramlara yönelik alıntıların analizi yapılmıştır.

K4: Covid-19 en sike görülen semptom ateşstir.

K98: Covid-19'da ateş, öksürük ve solunum sikintısi görülmektedir.

K32: Evde kalmak virüsïn yaynlmasin engeller.

Covid-19 özellikleri kategorisi altında katıllımc1ların "ateş", "öksürük" ve "yayılma” gibi kavramları ön plana çıkardıkları görülmektedir. Bu kavramlar Covid-19'a hastalığın gösterdiği özelliklerin bir sonucu olarak görülebilir.

\section{Kategori 5. Covid-19 Bulaşma Nedenleri}

Bu kategori altında Covid-19'a bulaşma nedenlerine işaret eden kavramlara yönelik alıntıların analizi yapilmıştır.

K67: Dünyada şu an gündemde olan Covid-19 ģok teblikeli bir virüs olmakla beraber büyüle solunum sıkentısı yaşatır.

K20: Korona, insanlarn korkutan ve hayat etkileyen bir virüstür.

Covid-19 özellikleri kategorisi altında katılımcıların "virüs" ve "korona” gibi kavramları ön plana çıkardıkları görülmektedir. Bu kavramlar Covid-19'un bulaşma nedenlerine işaret eden bulguları olarak değerlendirilebilir.

\section{Kategori 6. Covid-19'un Tedavisi}

Bu kategori altında Covid-19'a tedavisine işaret eden kavramlara yönelik alıntıların analizi yapılmıştır. K53: Salgin hastallk olan Covid-19 un aşıs bulunana dek sosyal mesafe kuralina ve yasaklara uyulmal.

K3: Sağhl̆̈ımı için gereksiz temaslardan kaçınarak virüslerden korunmaliyı yoksa bastane 'de tedavi süreci başlar.

Covid-19 tedavisi kategorisi altında katılımcıların "aşı" ve "bastane" gibi kavramları ön plana çıkardıkları görülmektedir. Bu kavramlar Covid-19'un tedavisine yönelik beklentilerin ve tedavi sürecinin bir göstermesidir.

\section{Kategori 7. Covid-19'un Taşıyıcıları}

$\mathrm{Bu}$ kategori altında Covid-19'un taşıyıcılarına işaret eden kavramlara yönelik alıntıların analizi yapılmıştır.

K2: Sağhl̆ğm korumak için insanlarla temastan kaçnmaliynz:

K45: Covid-19 testi pozitif çıkan tüm hayvanlarn, virüsü enfekte insanlarla yaken temastan sonra kaptĭgr dïsïnülïyor

K66: Sosyal mesafe ve kurallara nymaz isek virüsü ailemiž bulaștrabiliriz:

K102: Yakmmızda bir tassynce varsa hava yoluyla virüsü bize bulaşabilir.

Covid-19 taşıyıcıları kategorisi altında katılımcıların "insan", "bayvan", "aile” ve "bava" gibi kavramları ön plana çıkardıkları görülmektedir. Bu kavramlar Covid-19'un taşıyıcısı olabilecek canlı ve ortam özelliklerinin göstergesidir.

\section{Kategori 8. Covid-19 Korunma Yolları}

Bu kategori altında Covid-19'un korunma yollarına işaret eden kavramlara yönelik alıntıların analizi yapilmıştır.

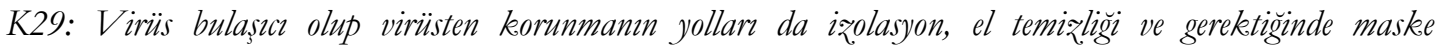
takmaktrr.

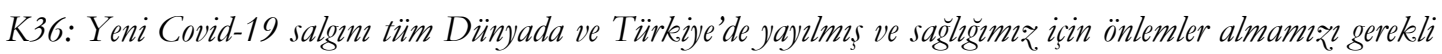
k.lmiştır.

K84: Salgin hastalı. nedeniyle evlerimizde karantina altunda kaldiğmmz, bu günlerde korkmadan, sakin kalarak, tüm sağhle ve temizlike tedbirlerini uygulamamı gerekli. 
K89: Karantina kurallarna uyarak ve sosyal mesafeyi koruyarak bu salgin hastaliktan korunabiliriz:

Covid-19 korunma yolları kategorisi altında katılımcıların "maske", "önlem”, "temizlike" ve "sosyal mesafe" gibi kavramları ön plana çıkardıkları görülmektedir. Bu kavramlar katılımcıların, Covid-19'dan korunma yollarına ait düşünce yapılarının göstergesidir.

\section{Kategori 9. Covid-19 Hastalık Sürecinin Özellikleri}

Bu kategori altında Covid-19’un hastalık sürecinin özelliklerine işaret eden kavramlara yönelik alıntıların analizi yapılmıştır.

K31: Virüs bulaşac olup virüsten korunmann yollar da izolasyon, el temiz̨lĭgi ve gerektiğinde maske takmaktır.

Covid-19 hastalık süreci özellikleri kategorisi altında katılımcıların "bulaşıc»" kavramını ön plana çıkardıkları görülmektedir. Bu kavramlar katılımcıların, Covid-19’un hastalık sürecinin özelliklerine ait yapılarının göstergesidir.

\section{Kategori 10. Covid-19 Basına Yansımaları}

Bu kategori altında Covid-19'un basına yansımaları sürecine özelliklerine işaret eden kavramlara yönelik alıntıların analizi yapılmıştır.

K34: Ülkemize gelen bu salgın hastalı nedeniyle sosyal hayatımıza ara verdik. Bundan dolayn da ev hapsi yaszyoruz: Evde deterjanlarla kendimizi bu salgzndan korumak için temizlik yapyoruz ve geri kalan bos vaktimizde de kitap okuyorur:

K83: Salgin hastalı geçene kadar kendi karantinamız̧ olusturup, önlemimiz̨i almalı ve kurallara uymaliyı:

Covid-19 basına yansımaları kategorisi altında "salgin”, "karantina” ve "ev hapsi” gibi kavramını ön plana çıkardıkları görülmektedir. Bu kavramlar katılımcıların, Covid-19 nedeniyle günlük hayatımıza giren yeni kavramların basın sayesinde geniş kitlelere ulaşması olarak düşünülebilir.

\section{Kategori 11. Covid-19 Görüldüğü Ülkeler}

Bu kategori altında Covid-19’un görüldüğü ülkelere ait özelliklerine işaret eden kavramlara yönelik alıntıların analizi yapılmıştır.

K24: Köpek, yarasa, yulan gibi canlular yaşam alanlarnda kalmalı. Cinlilerin yemesi yasaklanmal.

K37: Yeni Covid-19 salgın tüm Dünyada ve Türkiye de yayılmıs ve sağlğ̆ımı için önlemler almamıそ gerekli kelmistır.

Covid-19 görüldüğü ülkeler kategorisi altında “Cin” ve “Türkiye” gibi kavramını ön plana çıkardıkları görülmektedir. Bu kavramlar katılımcıların, Covid-19 salgının yayılma kaynağı olarak Çin’i görülmesinin bir sonucudur. Salgın tüm Dünya gibi Türkiye'yi de etkilemiştir. Ancak katılımcılar diğer ülkelerde de salgının görünmesine rağmen başka ülkelere ait kavram belirtmemişlerdir. Katılımcıların oluşturdukları kavramlardan yola çıkarak zihinsel yapılarının kavram hakkında bildikleri bazı yanılgılarında ortaya çıkarılmasını sağlayabilir.

Katılımcıların bilişsel yapılarında Covid-19'a yönelik kavram yanılgıları var mıdır? Alt problemine ilişkin bulgular

Kelime ilişkilendirme testi sonucunda oluşturulan 112 cümle incelenmiş, K12, K44, K62 ve K76 numaralı katılımcıların cümleleri şöyledir;

K12: Şu an ülkemizi hatta tüm dünyay saran hastalı yani Covid-19 herkesin en çokta cocuklarm psikolojisini etkilediğini düs̆̈̈üyorum.

K44: Mikeroplar birleşerek virüsü oluşturur, virüsler hastalıklar önlem alındiğı sürece iyileşme artar.

K62: Dünyada şu an gündemde olan Covid-19 çok teblikeli bir virüs olmakla beraber herkese büyük solunum sikentisi yasatır.

K76: Her seye zara verdik hayvanlarn yaşam alanlarna ağaçlara kuslarn yuvalarma o nedenle covid-19 yayild. 
K12, K44, K62 ve K76 numaralı katıllmcıların cümlelerinde kavram yanılg1ları olduğu görülmüştür. K12 katilımcısı virüsün en fazla "çocukları" etkilediğini ifade etmektedir. Bu genel itibari ile bilimsel bir ifade olmadığı görülmektedir. K44 katılımcısı "mikroplarnbirleșerek virüsleri” arttırdığını ifade etmiştir. Oysa mikroplar bakterileri, mantarları, arkeaları, protistleri, mikroskobik bitkileri (Yeşil algler); ve plankton, planarya ve Amoeba gibi mikro hayvanları da içine alan geniş bir çeşitlilik göstermektedir. K62 numaralı katılımc1 covid-19 virüsünün herkese "solunum sıkentıı" yaşattığını ifade etmişti. Halbuki Covid-19 virüsünün bazı kişilerde taşıyıcı olduğu, her bireyde aynı etkiyi yaratmadığı ifade edilmektedir. Katılımcılardan K76 "doğaya zarar" vermemiz nedeniyle Covid-19 virüsünün ortaya çıktığını belirtmiştir. Oysa Covid-19 virüsü doğanın tahrip edilmesi ile ortaya çıktı̆̆ını gösteren bir bulgu yoktur.

\section{Tartışma, Sonuç ve Öneriler}

Aralık 2019'da yeni bir koronavirüsün (SARS-CoV-2) Wuhan'da ortaya çıkmasıyla akut solunum sendromu (Covid-19) salgını üç ay içinde tüm dünyaya yayılmış ve bu da Dünya Sağllk Örgütü'nün bu durumu küresel bir salgın olarak (pandemi) ilan etmesine yol açmıştır. Covid-19 için aşı geliştirme çalısmaları sürerken, sosyal ve eğitim bilimleri alanında salgına yönelik yetersiz çalışma olduğu görülmüştür. Çünkü salgın tehdit alg1sı, yönetsel liderlik, bireysel ve kolektif çıkarlar, bilim iletişimi, sosyal bağlam, stres ve başa çıkma gibi boyutlarda kişiler ve toplumlar arasında birçok etkiye sebep olmuştur (Van Bavel vd., 2020, s. 461). Bu araştırmada üniversite öğrencilerinin Covid-19 virüsü hakkında yönetsel liderlik ve bireysel etkileri hakkında sahip oldukları bilişsel yapılar belirlenmeye çalışılmışır.

Üniversite öğrencilerinin Covid-19 hakkındaki bilgi alma kaynakları incelendiğinde Covid-19 virüs salgını hakkında daha çok televizyon ve sosyal medyayı takip ettikleri görülmektedir. Bu güncel bilgi kaynakları olarak görülebilir. Katılımcıların bilgi edinmek için öncelikle televizyon ve radyo gibi kaynakları kullandıkları görülmektedir. Katılımcıların salgın hakkında güven duyduğu kaynaklar incelendiğinde katılımcıların Sağlık ve İçişleri Bakanlığı aracılığı ile sunulan kaynaklara güvendikleri görülmektedir. 20142015 Batı Afrika Ebola krizinden yapılan araştırmalar, sağlık görevlilerine bağllık ve güven geliştirmeye yardımcı olmak için yerel yöneticiliğin liderliği bu tür halk sağllğı önlemlerinin başarısını artırabileceğini göstermiştir (Tsai, Morse ve Blair, 2020, s. 12). Dolayısıyla katıllımcıların gözünde Sağlık ve İçişleri Bakanlığının salgın süreci hakkında yürüttükleri uygulamalarının güven yarattı̆̆ı görülmektedir. Salgın süreci başladığından beri, Sağlık Bakanlığının gündelik bilgilendirme yaparak süreci iyi yönettiğinin bir göstergesidir. Kurum ve kuruluşların süreçte yaptıkları çalışmalar değerlendirildiğinde Sağlık ve İçişleri Bakanlığı gibi kurumların çalışmalarının diğer kuruluşlara göre daha iyi değerlendirildiği bir başka sonuçtur.

Üniversite öğrencilerinin bağımsız kelime ilişkilendirme testi kullanılarak "Covid-19" kavramı konusundaki bilişsel yapılar 11 kategori alında toplanmışır. Bu kategoriler Covid-19 sonuçları, bulaşma yolları, Covid-19'a yönelik algılar, özellikleri, bulaşma nedeni, tedavisi, taşıyıcıları, korunma yolları, hastalık sürecinin özellikleri, basına yansımaları Covid-19 görüldüğü ülkeler olmak üzere 11 kategoriye ayrılmıştır. Bu kategorilerden en fazla tekrarlanan alanın Covid-19'a yönelik algilar olduğu görülmektedir. Bu kategori altında en fazla, sağlık ve yaşam alanı olarak tekrarlandığı görülmektedir. Salgın hastalığın sağlığımızı olumsuz olarak etkilemesinin yanında, salgının başlamasının ardından yaşam alanımız dış ev ortamına doğru değişmesine neden olmuştur. Ancak bireylerin uzun süre evde kalması, onların doğaya karşı özlem duyduğunu göstermektedir. Bu nedenle algılar bölümünde en çok doğa, çevre gibi kavramların tekrar etmesi yaşam alanlarının sınırlandığının göstergesidir. İkinci olarak, Covid-19 virüsünün neden olduğu salgının korunma yolları kategorisi incelendiğinde katılımciların sıklıkla maske, önlem, temizlik, sosyal mesafe, dezenfektan gibi hayatımıza yeni giren kavramların tekrar ettiği görülmektedir. Üçüncü kategoride Covid-19 virüsünün bulaşma yolları olarak insan, hayvan ve aile gösterilmektedir. Bu bulgular katılımcıların Covid-19 virüsünün neden olduğu hastalığa yakalanmaktan tedirgin olduklarının bir göstergesi olarak yorumlanabilir. Salgın süreci ayrıca fen eğitiminin en temel konularından biri olan mikroorganizmaların günlük hayat problemleri ile iç içe olduğunu göstermiştir. O nedenle elde edilen kategoriler dikkate alınarak fen eğitim içeriklerinin düzenlenmesine katkı sunabilir.

Katıllımciların küçük bir bölümünün Covid-19 virüsünün neden olduğu salgın hakkında kavram yanılgılarına da sahip oldukları görülmüştür. Bunun nedeni güvenilir olmayan kaynakları takip etme sıklıkları olabilir. Bu nedenle Covid-19 hastalığın daha iyi kontrol edilmesine yardımcı olan salgın, patojenite ve bulaşabilirlik hakkında halka güncel, zamanında, doğru, şeffaf, kısa, basit bilgi ve bilgi sağlamak Covid-19 salgını ile ilgili resmi ve güvenilir bilgiler sunan erişilebilir platformlar sağlamak kritik öneme sahiptir (Chen, 2020, s. 70). 
Davranış bilimleri açısından bakıldığında elde edilen bulguların virüsün sağlık ve yaşam alanında olumsuz etkiler yarattığı görülmektedir. Covid-19'un potansiyel olarak yıkıcı etkileri sadece virüsün sebep olduğu hastalığa yakalanmanın yanından davranışsal olarak stres, panik, kaygı, riskli tutumlar gibi davranış problemlerinin ortaya çıkmasına neden olacağını göstermektedir. Bu etkilerin zaman içerisinde eğitim bilimlerine yansıması beklenmektedir. Çünkü salgın, eğitim uygulamalarını da değiştirmiş, öğrenciler ve eğitimciler uzaktan eğitim süreçlerine uyum sağlamaya çalışmışlardır. Salgın süreci, eğitim açısından bilimin ve bilimsel bilginin öneminin de arttığını göstermiştir. Bu nedenle salgın sürecinin eğitime yansımaları araştırılabilir. Bu araştırmada kısıtlı bir çerçevede katılımcıların bilişsel yapıları belirlenmeye çalışılmıştır. Katılımcıların niceliksel ve niteliksel özellikleri dikkate alınarak farklı yaş grupları ve demografik özellikleri bağlamında farklı ölçme araçları ile desteklenmesi önerilebilir.

\section{Etik Beyan}

"Üniversite Ögrrencilerinin Covid-19 Virüsü Hakekenda Bilissel Yapularmm Belirlenmesi” başlıklı çalısma 29.05.2020 tarih ve 2020/08-13 sayılı Zonguldak Bülent Ecevit Üniversitesi İnsan araştırmaları Etik Kurul Kararı ile onaylanmıştır. Araştırmanın yazım sürecinde bilimsel, etik ve alıntı kurallarına uyulmuş; toplanan veriler üzerinde herhangi bir tahrifat yapılmamıstır. Çalısma başka bir akademik yayın ortamına değerlendirme için gönderilmemiştir.

\section{Kaynakça}

Atasoy, B. (2004). Fen ögrenimi ve ögretimi. Ankara: Asil Yayınevi.

Bahar, M., Johnstone A. H., ve Sutcliffe, R. G. (1999). Investigation of students' cognitive structure in elementary genetic through word association tests. Journal of Biological Education, 33(3), 134-141.

Can, E. (2020) Coronavirüs (Covid-19) pandemisi ve pedagojik yansımaları: Türkiye'de açık ve uzaktan eğitim uygulamaları. Aģıögretim Uygulamalarn ve Arastrmalar Dergisi, 6(2), 11-53.

Chen, J. (2020). Pathogenicity and transmissibility of 2019-nCoV-A quick overview and comparison with other emerging viruses. Microbes and Infection, 2(22), 69-71. doi: 10.1016/j.micinf.2020.01.004.

Dünya Sağllk Örgütü [WHO] (2019). Corona virüs disease (COVID-19) advice for the public. Erişim adresi: https://www.who.int/emergencies/diseases/novel-coronavirus-2019/advice-for-public

Ekici, G., Gokmen, A., ve Kurt, H. (2014). Öğretmen adaylarının "Bilgisayar" kavramı konusundaki bilisssel yapılarının belirlenmesi. Gazi Universitesi Gazi Egitim Fakiltesi Dergisi, (34)3, 357-401.

Ekici, G. ve Kurt, G. (2014). Öğretmen adaylarının “AIDS” kavramı konusundaki bilişsel yapıları: bağımsız kelime ilişkilendirme testi örneği. Türkije Sosyal Arasttrmalar Dergisi, 183 (183), 267-306.

Gerçek, C. (2020). Lise öğrencilerinin bilişsel yapıları ve görüşleri: genetiği değisstirilmiş organizma nedir? Eğitimde Nitel Araştrmalar Dergisi, 8(1), 96-106.

Halk Sağlığı Genel Müdürlüğ̈ [HSGM] (2020). COVID-19 (Yeni Koronavirüs Hastalığı)'na Yakalanmamak İçin Öneriler. Erişim adresi: https://hsgm.saglik.gov.tr/tr/covid-19-yeni-koronavirus-hastaligi-na-yakalanmamak-icin-oneriler

Hruschka, D.J., Schwartz, D., St.John, D.C., Picone-Decaro, E., Jenkins, R.A., ve Carey, J.W. (2004). Reliability in coding open-ended data: Lessons learned from HIV behavioral research. Field Methods, 16(3), 307-331.

John Hopkins Corona Virus Research Center (2020). COVID-19 Dashboard by the Center for Systems Science and Engineering (CSSE) at Johns Hopkins University (JHU). Erişim adresi: https://coronavirus.jhu.edu/map.html

Kırık, A., Özkoçak, V. (2020) Yeni Dünya düzeni bağlamında sosyal medya ve yeni koronavirüs (Covid-19) pandemisi. Akademike Sosyal Arastrtrmalar Dergisi. 7(45), 134-148. doi: 10.29228/SOBIDER.43146.

Kostova, Z., ve Radoynovska, B. (2008). Word association test for studying conceptual structures of teachers and students. Bulgarian Journal of Science and Education Policy, 2(2), 209-231.

Kurt, H. (2013). Biyoloji öğretmen adaylarının enzim konusundaki bilişsel yapılarının belirlenmesi. Gazi Eğitim Fakilltesi Dergisi, 33(2), 211-243.

Kurt, H. ve Ekici, G. (2013). Biyoloji öğretmen adaylarının bağımsız kelime ilişkilendirme testi ve çizme-yazma tekniğiyle "Osmoz" kavramı konusundaki bilişsel yapılarının belirlenmesi. Elektronik Türkşe Dergisi, 8(12), 809829.

Li, Q., Guan, X., Wu, P.....Med, M. (2020). Early transmission dynamics in Wuhan, China, of novel coronavirusinfected pneumonia. N EnglJ Med 382,(1), 199-207. doi:10.1056/NEJMoa2001316.

Lugo, M. J. M. (2020). COVID-19 in Post-Truth Societies, Erişim adresi: https://www.caracaschronicles.com/2020/04/16/covid-19-in-post-truth-societies/

Miles, M.B., ve Huberman, A.M. (1994). Qualitative data analysis. Thousand Oaks, CA: Sage.

Roberts, P., ve Priest, H. (2006). Reliability and validity in research. Nursing Standard, 20, 41-45.

Sato, M., ve James, P. (1999). "Nature" and "Environment" as perceived by university students and their supervisors. International Journal of Environmental Education and Information, 18(2), 165-172.

Shavelson, R. J. (1974). Methods for examining representations of subject-matter structure in a student's memory. Journal of Research in Science Teaching, 11, 231- 249. 
Stake, R. E. (1995). The art of case study research. Thousand Oaks: Sage Pbc.

Suri, H. ve Clarke, D. (2009). Advancements in research systhesis methods: From a methodologically inclusive perspective. Review of Educational Research, 79(1), 395-430.

Torkar, G., ve Bajd, B. (2006). Trainee teachers' ideas about endangered birds. Journal of Biological Education, 41(1), 5-8.

Timur, B., ve Taşar, M. F. (2011). Developing pre-service science teachers' cognitive structures about technology: Word association test (WAT). Western Anatolia Journal of Educational Sciences, 20(11), 131-138.

Tsai, L. L., Morse, B. S. ve Blair, R. A. (2020). Building credibility and cooperation in low-trust settings: persuasion and source accountability in Liberia during the 2014-2015 Ebola crisis. Comp. Polit. Stud. (20), 1-20. doi: 10.1177/0010414019897698

Van Bavel, J. J., Boggio, P., Capraro, V., Cichocka, A., Cikara, M., Crockett, M., Willer, R. (2020). Using social and behavioural science to support COVID-19 pandemic response, (4), 461-471. doi:10.31234/osf.io/y38m9

West, L. H. T., Fensham, P. J. ve Garrard, J. E., (1985). Describing the cognitive structures following instruction in chemistry, West L.H.T. ve Pines A.L. (Ed.) Cognitive Structures and Conceptual Change. 29-49. Orlando: Academic Press.

Yıldırım, A. ve Şimşek, H. (2011). Sosyal bilimlerde nitel araştırma yöntemleri. Ankara: Seçkin Yayıncılık.

Yin, R. K. (2014). Case study methods: design and methods. Thousand Oaks: Sage Pbc.

Zarocostas, J. (2020). How to fight an infodemic. The Lancet, 395(10225), 676.

Zhang, Y., ve Ma, Z. F. (2020). Impact of the COVID-19 pandemic on mental health and quality of life among local residents in Liaoning Province, China: A cross-sectional study. International journal of environmental research and public bealth, 17(7), 2381.

\section{EXTENDED ABSTRACT}

Crises have caused new habits (virus, pandemic, social isolation, quarantine) to enter our lives as well as changing the habits of the societies. Having a wide usage area makes the concept of virus one of the concepts that are difficult to learn and teach and causes them to have difficulty in forming their cognitive structures. Cognitive structure is a hypothetical structure that symbolizes the relationships of concepts in a person's long-term memory. Topics such as how individuals think, remember, organize information are among the most important and researched topics of educational research for years. The pandemic situation caused by Covid-19 virus, which has become a major problem today, seems to have an impact on both social studies and educational practices. In addition, research into the Covid-19 virus is ongoing. The virus has significant gaps in the literature in the fields of health, politics, health and education. Findings and conclusions regarding education should be interpreted with caution, because there is little published research on the Covid-19 process. The findings to be obtained in the research are thought to contribute to future studies.

The purpose of this research is to determine the cognitive structures of university (associate and undergraduate) students about the concept of Covid-19. In this research, case study, one of the qualitative research methods, was used. It is a desire to understand case studies of complex social phenomena (Stake, 1995, p. 12; Yin, 2014, p. 45). The study group of this research consists of 112 participants from 36 provinces. The data collection tool consists of two parts. In the first part, where do you get information about Covid-19 besides the demographic features such as the participant's age, gender, and city? What sources do you trust about the measures to be taken to prevent Covid-19 disease? About the management of the Covid-19 Outbreak emergency, how do you evaluate the work of the following institutions, organizations, people? Questions such as were asked. In the second part, word association test is used to determine the cognitive styles of the participants regarding the concept of Covid-19. In the process of analyzing and interpreting the content; (1) the coding and extraction phase is transferred to the given excel obtained by Google form and arranged as frequency tables. 536 frequencies were obtained. However, it has been omitted because the frequency value of some concepts is 1 . Therefore, 439 concepts were examined. (2) The category development phase was organized by taking into consideration the categories examined by Ekici and Kurt (2014, p. 291), (3) validity and reliability phase, (4) reporting phase, has been carried out in four stages (Yıldırım and Şimşek, 2011, p. 39).

Cognitive structures on the concept of "Covid-19" were gathered under 11 categories using the independent word association test of university students. These categories are divided into 11 categories: Covid-19 results, ways of transmission, perceptions about Covid-19, its features, cause of infection, treatment, carriers, ways of protection, features of the disease process, reflections to the press and countries in which Covid-19 is seen. It is seen that the most repeated area among these categories is perceptions about covid-19. It is seen that this category is most frequently repeated as a health and living area. In addition to the epidemic affecting our health negatively, our living space has changed towards the external home environment after the outbreak started. However, the fact that individuals stay at home for a long time shows that they yearn for nature. For this reason, the repetition of concepts such as nature 
and environment in the perceptions section is an indication that the living spaces are limited. Secondly, when the category of ways to protect the epidemic caused by Covid-19 virus is examined, it is seen that the participants frequently repeat concepts such as mask, precaution, cleaning, social distance, disinfectant. In the third category, human, animal and family are shown as the transmission routes of Covid-19 virus. These findings can be interpreted as an indication that participants are worried about getting the disease caused by covid-19 virus.

A small number of participants were also found to have misconceptions about the outbreak caused by Covid-19 virus. This may be due to the frequency of tracking untrusted sources. Therefore, it is critical to provide accessible platforms that provide official and reliable information about the covid-19 outbreak, providing the public with up-to-date, timely, accurate, transparent, short, simple information and information about the epidemic, pathogenicity and contagiousness that helps better control the disease (Chen, 2020, p. 70).

In terms of behavioral sciences, it is seen that the findings have negative effects on the health and life of the virus. The potentially devastating effects of Covid-19 show that not only the disease caused by the virus will cause behavioral problems such as behavioral stress, panic, anxiety, or risky attitudes. These effects are expected to reflect on educational sciences over time. Because the epidemic also changed educational practices, students and educators tried to adapt to distance education processes. The epidemic process has shown that the importance of science and scientific knowledge has also increased in terms of education. For this reason, in order for the societies to overcome the health problems that may arise in the future, education should be developed in education policies aimed at raising the quality workforce that will grow in the field of health in the future. 